\title{
変形性肩関節症に対する人工肩関節置換術（DePuy）の小経験
}

福岡大学医学部整形外科
湯 朝 友 基・柴 田 陽 三
緑 川 孝 二・武 田
城 石 達 光

\section{Total Shoulder Replacement for Glenohumeral Osteoarthritis Using Global system (Depuy)}

by

\author{
Tomoki Yuasa, Yozo Shibata, Koji Midorikawa, \\ Ken Takeda and Tatsuhiro Shiroishi \\ Department of Orthopaedic Surgery, Fukuoka university, School of Medicine
}

\begin{abstract}
DePuy total shoulder replacements were performed on two patients for glenohumeral osteoarthritis.

Patients were 69 and 72 year old females both of whom suffered from severe right shoulder pain and disability. Plain $\mathrm{X}$-ray films revealed severe osteoarthritic changes in both patients, but arthrogram and MRI did not show a rotator cuff tear.

The fixation of each components was as follows. Glenoid components were fixed with cement, but humeral components were press-fitted without cement. DePuy's humeral component is capable of tissue-ingrowth and has four fins on the component to ensure rotarory stability. On the fourth post operative day, passive range of motion exercises were started.

The follow-up period was one year and ten months in each case. The results were evaluated according to J. O. A score. Both patients achieved pain relief and improved their shoulder range of motion. Radio lucent line around the glenoid component was recognized on $\mathrm{X}$-ray films at an early post operative state.

But one year after surgery, the width of this lucent line had not increased. Although follow-up is relativery short, both patients are satisfied with their shoulder function.
\end{abstract}

Key words : Gulenohumeral Osteoarthritis (変形性肩関節症), Total Shoulder Replacement (人工肩 関節置換術)

はじめに

変形性肩関節症は股関節・膝関節などの荷重関節に 比べ, 発生頻度は少なく, 中でも原因不明の一次性は 極めて稀とされている. 今回我々は，特に誘因なく発 症し，関節造影・MRI 上明らかな腱板断裂を認めな い一次性変形性肩関節症 2 症例に対して, DePuy 社
製人工肩関節を用い置換術を施行したので，報告する．

\section{手術方法・後療法}

関節窝コンポーネントはセメント固定とし，上腕骨 コンポーネントはセメントを使用せず挿入した，術後 は外転装具固定とし, 術後 4 日目より他動関節可動域 訓練を開始した。 


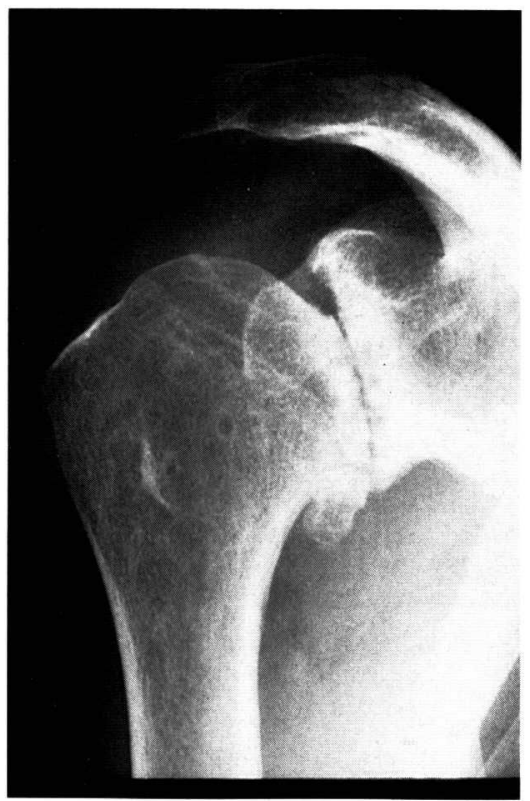

a) 肩関節前後像

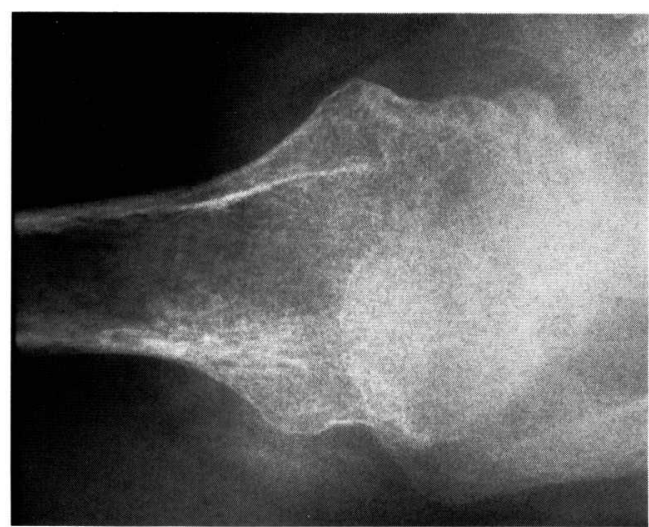

b ）肩関節軸射像

図 1 症例 1 の単純 X線像

前後像並びに軸射像にて関節裂隙の狭小化と骨棘形成を認める.

表 1 術前・術後の J・O ・ A score

\begin{tabular}{c|c|c|r|r|r|r}
\multicolumn{5}{|c|}{ 結果 } \\
\hline \hline & \multicolumn{3}{|c}{ 症例 1 } & \multicolumn{3}{c}{ 症例 2} \\
\hline & 術前 & 術後 & 改善 & 術前 & 術後 & 改善 \\
\hline 疼痛 & 10 & 25 & 15 & 5 & 25 & 20 \\
機能 & 13.5 & 19.5 & 6 & 4 & 18 & 14 \\
可動域 & 18 & 24 & 6 & 11 & 20 & 9 \\
X線所見 & 1 & 5 & 4 & 1 & 5 & 4 \\
関節安定性 & 15 & 15 & 0 & 15 & 15 & 0 \\
\hline 総合評価 & 57.5 & 88.5 & 31 & 37 & 83 & 47 \\
\hline
\end{tabular}

結 果

日整会肩関節疾患治療成績判定基準を用いておこなっ た. 症例 1 で, 術後 31 点・症例 2 で, 術後 47 点の改 善を認めた。両症例とも疼痛の項目での改善が高く, 症例 2 においては, 術前低かった機能の項目の改善も 著しかった（表1）.

症 例

症例 $1: 69$ 歳, 女性

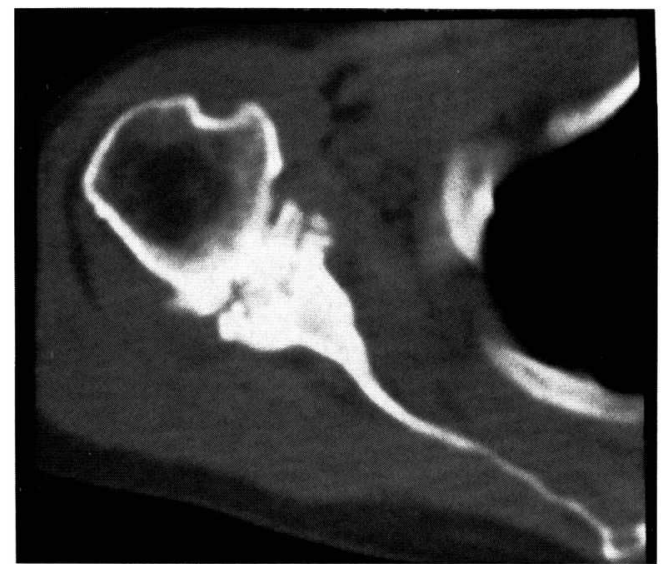

図 2 症例 1 の C T 像

骨棘形成はいっそう明らかとなり， 関節窩側には亀裂の形成を認める。

主訴：右肩痛および挙上困難

現病歴 : 94 年誘因なく右肩痛および挙上困難が出 現した. 95 年 3 月当科受診.

現症 : 右肩関節可動域は制限を認めた。 ツ反・関節 


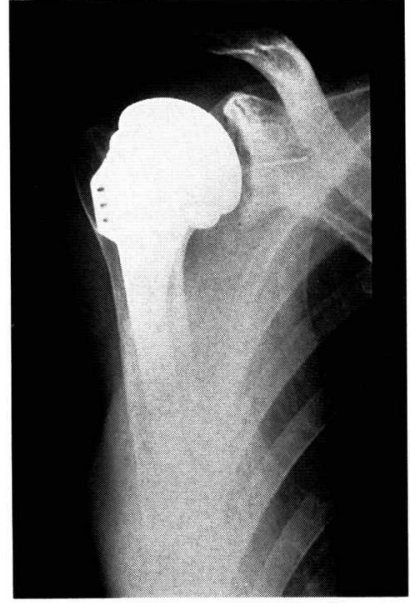

a ）肩関節前後像

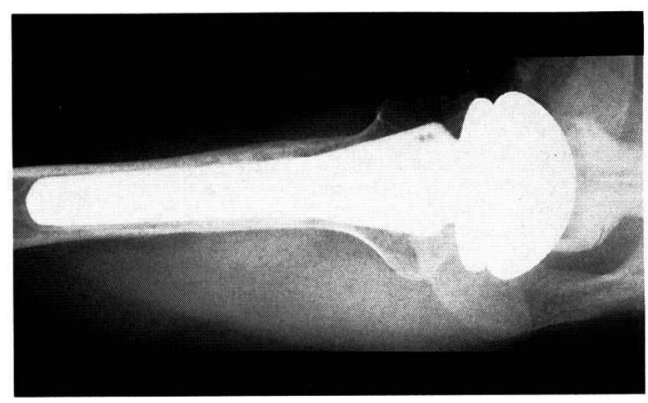

b ）肩関節軸射像

図 3 症例 1 の術後X線像

術後 1 年の単純X線像で人工関節の適合性は良好, 上腕骨コンポーネント先端には骨硬 化像を認める，関節窩コンポーネントの上方部分には $1 \mathrm{~mm}$ の lucent line を認める.

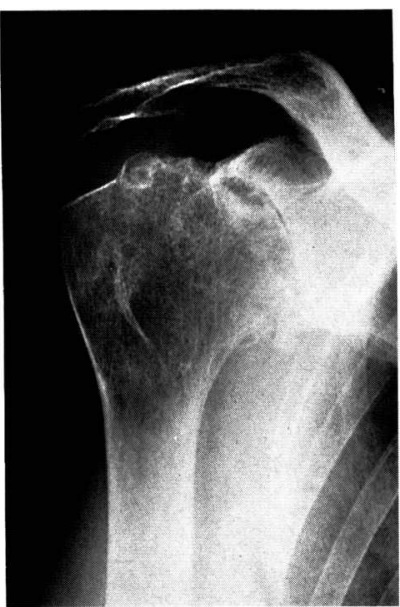

a) 肩関節前後像

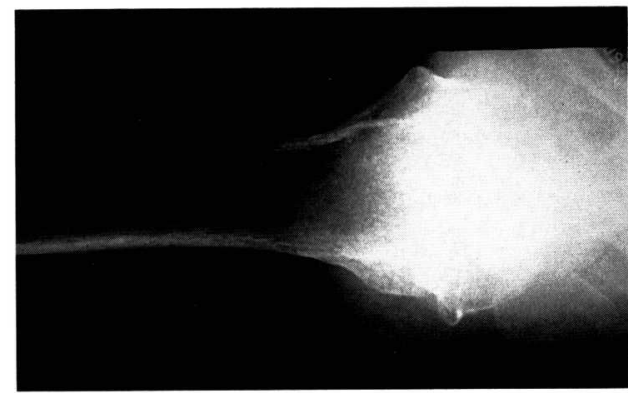

b）肩関節軸射像

図4 症例 2 の単純 $X$ 線像 骨頭関節軟骨下に骨褁包を認め，関節裂隙は消失している.

液培養ともに陰性であった。

画像所見 : 単純 X 線では関節裂隙の狭小化および 上腕骨骨頭の内下方に骨棘形成を認めた（図 $1-a, b)$. CT では，強い関節症性变化を認めた（図 2 ).

術後 1 年の画像所見: 術直後から関節窩コンポーネ ント上方に 1 ミリの lucent line を認めていたが， そ の拡大は認めない（図 $3-\mathrm{a}, \mathrm{b}$ ).
症例 $2: 72$ 歳, 女性

主訴: 右肩痛および挙上困難

現病歴 : 90 年頃より誘因なく右肩痛が出現した. 95 年 4 月増強し, 可動域制限も認めるため, 9 月当 科受診。

現症 : 右肩関節可動域は制限を認めた。 ッ反・関節 液培養ともに陰性であった。 
画像所見 : 単純 X 線では, 関節裂隙の狭小化およ び上腕骨骨頭の内下方に骨棘形成を認めた（図 $4-a$, b). CT では，関節窩の bone stock の減少を認めた (図 5 ).

術後 10 力月の画像所見：明らかな lucent line は 認めない（図6-a,b).

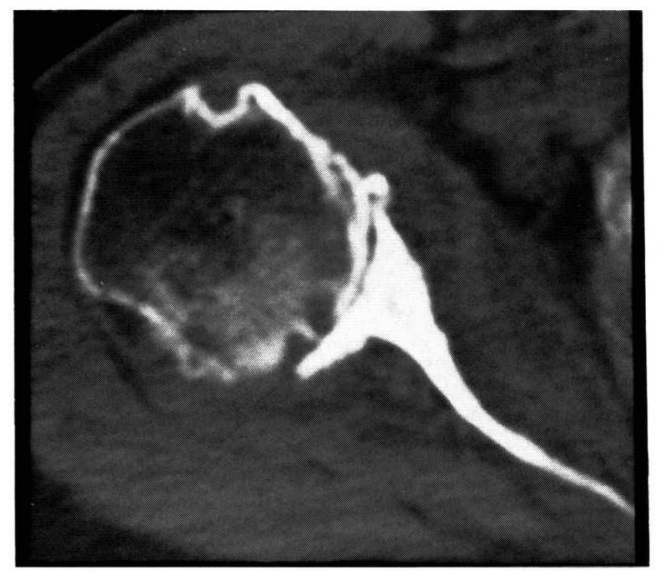

図 5 症例 2 の C T像

骨頭関節軟下骨に骨量包像を認め，関節軟 骨が消失している，関節窩側は erosion を 生じ, bone stock の消失を認める.

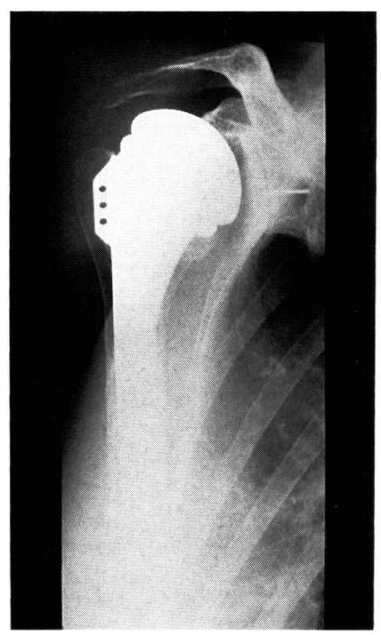

a ) 肩関節前後像

$$
\text { 考察 }
$$

変形性肩関節症の治療目的として疼痛や可動域の改 善, 支持性の向上が挙げられるが, 症状・年齢・支持 する肩関節の機能などを考慮してその治療法が選択さ れる. 保存療法が効果をみない際には, debridment, 関節固定術，人工肩関節置換術（以下 TSR と略す） などの適応が考慮される.

Neer，Cofield らは腱板機能が保たれている変形性 肩関節症はTSR のもっともよい適応之述べ，良好な

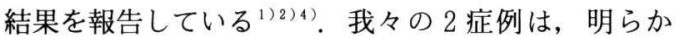
な腱板断裂を認めず，誘因なく発症していることから 一次性変形性肩関節症と考え, 疼痛の程度・年齢など から TSR を選択した.

Neerにより total shoulder system は広く臨床応 用されるようになり, 現在までに様々な機種が開発さ れている，その中で, 今回我々は, セメントレスステ ムでより強固な上腕骨の固定を期待したいために, 中 枢側のステム径が太く, bone-ingrowth を可能にす るコーティングと回旋安定性を向上させる，4枚のフィ ンを有する DePuy 社製の Global type を使用してみ た

関節窩コンポーネントにセメントを使用するか否か は双方に一長一短があり, Cofield は明確にその適応 の違いを述べることは困難であるとしている ${ }^{2)}$. セメ ント使用の場合, lucent line の発生頻度は 30\%〜80 \%という報告が過去にある2)4 . Neer はその進行を認 めなかったと報告したが4)，Cofield・Hawkins らは 頻度は低いが進行を認めたと報告している ${ }^{2) 3)}$.

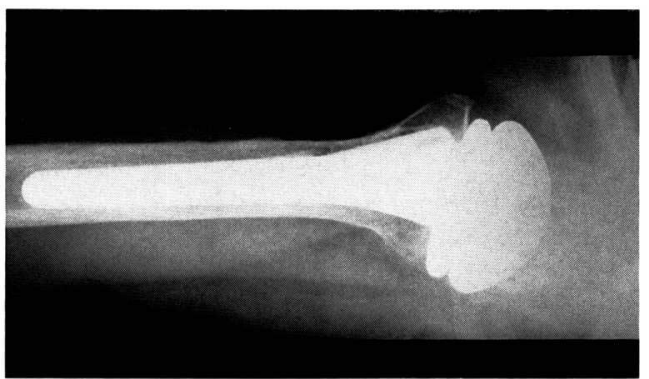

b ）肩関節軸射像

図 6 症例 2 の術後 X 線像

術後 10 力月の単純 $X$ 線像で人工関節の適合性は良好で, 上腕骨側, 関節窩側 のコンポーネントともに明らかな lucent line は認めない. 
Wirth らは lucent line の存在や進行は将来的にはコ ンポーネントの loosening を生じてくるのではない かと推察している ${ }^{5)}$. 今回 1 症例で, 関節窝コンポー ネント上方に術後早期から lucent zone を認めており, 今後注意潹く経過を観察していきたい.

$$
\text { ま と め }
$$

变形性肩関節症 2 例に対して, 人工肩関節置換術 （DePuy 社製 Global type）を施行し短期成績ではあ るが, 満足できる結果を得ている.

\section{参考 文 献}

1) Barret, W. P. et al. : Total shoulder arthroplasty. J. Bone and Joint Surg., 69- A : 865-872, 1987.

2) Cofield, R. H. : Total shoulder arthroplasty with the Neer prosthesis. J. Bone and joint Surg., 66- A : 899-906, 1984.

3) Hawkins, R. J., Bell, R. H. and Jally, B. : Total shoulder arthroplasty. Clin. Orthop., 242 : 188-194, 1889.

4) Neer, C. S. II : Recent experience in total shoulder replacement. J. Bone and Joint Surg., 64 - A : 319-337, 1982.

5) Wirth, M. A. and Rockwood, C. A. Jr. : Complications of total shoulder-replacement arthroplasty. J. Bone and joint Surg., 78-A : 603-616, 1996. 